\title{
Social Identity and Social Exchange: Identification, Support, and Withdrawal From the Job
}

\author{
DAAN VAN KNIPPENBERG ${ }^{1}$ \\ Erasmus University Rotterdam \\ Rotterdam, The Netherlands
}

\author{
ROLF VAN Dick \\ Aston University \\ Birmingham, UK \\ and \\ Goethe University \\ Frankfurt, Germany
}

\author{
Susana TAVARES \\ Higher Institute of Social Sciences and Business Studies \\ Lisbon, Portugal
}

\begin{abstract}
Integrating insights from the social exchange perspective and the social identity perspective, we propose that evaluations of support received from the organization and its representatives and organizational identification interact to predict withdrawal from the job. The relationship of support with withdrawal is proposed to be weaker the more strongly employees identify with the organization. This prediction was confirmed in 2 samples focusing on different operationalizations of support and withdrawal. Study 1 explored the interaction between organizational support and organizational identification in predicting turnover intention; Study 2 investigated the link between supervisor support and organizational identification and absenteeism. The present study thus yields evidence that may lay the groundwork for further integration of social exchange and social identity analyses of organizational behavior.
\end{abstract}

The psychological relationship between the individual and the organization is an important factor in organizational behavior (Ashforth \& Mael, 1989; Hogg \& Terry, 2000; Meyer \& Allen, 1997; Rhoades \& Eisenberger, 2002; Rousseau \& Parks, 1993). Employees may, to a greater or lesser extent, conceive of themselves in terms of their membership in the organization. Thus, the magnitude of individuals' attachment to the organization and the evaluation they make of the relationship that the organization develops with them may exert an important influence on job-related attitudes and behavior, such as absenteeism and turnover (intentions) (e.g., Eisenberger, Huntington,

${ }^{1}$ Correspondence concerning this article should be addressed to Daan van Knippenberg, RSM Erasmus University, Erasmus University Rotterdam, P.O. Box 1738, 3000 DR, Rotterdam, The Netherlands. E-mail: dvanknippenberg@rsm.nl 
Hutchison, \& Sowa, 1986; Mael \& Ashforth, 1995; Meyer \& Allen, 1997; Riketta \& van Dick, 2005); in-role behavior (e.g., Armeli, Eisenberger, Fasolo, \& Lynch, 1998; James \& Greenberg, 1989); and extra-role behavior (e.g., Christ, van Dick, Wagner, \& Stellmacher, 2003; Podsakoff, MacKenzie, Paine, \& Bachrach, 2000). Understanding the psychological relationship between the individual and the organization, therefore, is of great theoretical and practical relevance for research in organizational behavior.

In recent years, two perspectives on the psychological relationship between the individual and the organization have been receiving increasing attention: the social exchange perspective (e.g., Rhoades \& Eisenberger, 2002; Rousseau \& Parks, 1993), and the social identity perspective (e.g., Ashforth \& Mael, 1989; Hogg \& Terry, 2000). So far, these perspectives have developed largely in isolation from each other. To move toward a more integrated understanding of the psychological relationship between individual and organization, in the present study we integrate insights from both perspectives. Specifically, we propose that evaluations of the exchange relationship with the organization, as evident in evaluations of the support received from the organization and its representatives and organizational identification interact in predicting withdrawal from the job.

Withdrawal from the job is a concern to organizations (Cascio, 1982). It is also particularly relevant in an analysis of the psychological relationship between individual and organization because it involves withdrawing from this relationship either temporarily (i.e., absenteeism, lateness) or permanently (i.e., turnover). Accordingly, focusing on withdrawal from the job helps to explicate how the social exchange and social identity approaches to individuals' attachment to the organization may be integrated. Studies of job withdrawal have shown withdrawal intentions and behavior to be related to a variety of factors, including job satisfaction, organizational justice, organizational commitment, work group norms, and labor market conditions (Griffeth, Hom, \& Gaertner, 2000; Johns, 2001; Riketta, 2005). Of particular relevance to a conceptual integration of social exchange and social identity perspectives on the psychological relationship between the individual and the organization, withdrawal also has been shown to be contingent on social exchange and social identity processes, and the remainder of this discussion focuses on these processes as predictors of job withdrawal.

First, we will outline the social exchange perspective and the social identity perspective on the relationship between the individual and the organization, particularly on withdrawal from the job. Then, we will zoom in on the proposition advanced in this study: Social exchange processes and social identification processes interact in predicting withdrawal from the job. 


\section{Social Exchange and Organizational Behavior}

Central to the social exchange perspective on the employee-organization relationship is the assumption that the relationship between employees and their employer is built on the trade of effort and loyalty for benefits such as pay, support, and recognition (Blau, 1964; Levinson, 1965; Rhoades \& Eisenberger, 2002; Rousseau \& Parks, 1993). Accordingly, employees' evaluation of the quality of their exchange relationship with the organization and its representatives (i.e., leaders, supervisors; Levinson, 1965) is predictive of their attitudes and behavior. The better the perceived quality of the exchange relationship (i.e., benefits received from the other party are high and up to par with one's own input in the relationship), the more motivated individuals are to exert themselves on behalf of the other party and to remain within the relationship. This motivation is proposed to flow from a norm of reciprocity that prescribes that benefits received should be repaid in kind (Eisenberger, Armeli, Rexwinkel, Lynch, \& Rhoades, 2001; Gouldner, 1960).

Research has operationalized these social exchange processes largely in terms of evaluations of the exchange relationship. Eisenberger et al. (1986) proposed the concept of perceived organizational support to reflect the individual's evaluation of the organization's role in the exchange relationship. Perceived organizational support refers to global perceptions of the extent to which the organization values the individual's contribution and cares about the individual's well-being (Eisenberger et al., 1986; Rhoades \& Eisenberger, 2002).

In a similar vein, Rousseau and colleagues (e.g., Robinson \& Rousseau, 1994; Rousseau \& Parks, 1993) conceptualized the psychological contract between individual and organization from a social exchange perspective, proposing that the psychological contract between individual and organization is the individual's beliefs regarding reciprocal obligations in this exchange relationship. Research also has focused on evaluations of support received from the supervisor (Kottke \& Shafranski, 1988; Shore \& Tetrick, 1991). Levinson (1965) argued that the relationship between the individual and the organization often is enacted through the relationship with representatives of the organization (e.g., leaders, supervisors). Accordingly, employees' evaluations of their relationship with these representatives and of their relationship with the organization as a more abstracted entity may merge, to a certain extent. Viewed slightly differently, evaluations of the exchange relationship with organizational representatives also may be seen as a precursor to evaluations of the relationship with the organization (Eisenberger, Stinglhamber, Vandenberghe, Sucharski, \& Rhoades, 2002; Rhoades \& Eisenberger, 2002).

In support of the view that evaluations of the support received from the organization and its representatives reflect social exchange processes, research 
has shown that the relationship between evaluations of organizational support and outcomes is mediated by the felt obligation to reciprocate the organization's support (Eisenberger et al., 2001). Further validating evaluations of support as an indicator of social exchange processes, other studies have shown that organizational support is related more strongly to outcomes for individuals with a stronger exchange orientation (Eisenberger et al., 1986), and less strongly the more individuals do not trust the organization to reciprocate (Lynch, Eisenberger, \& Armeli, 1999). Corroborating this argument, Eisenberger, Cummings, Armeli, and Lynch (1997) outlined how the social exchange analysis implies that organizational support is only an exchange commodity when it is given voluntarily. Accordingly, support should only engender the motivation to reciprocate to the extent that the support is seen as being discretionary. Indeed, Eisenberger et al. (1997) showed that the extent to which organizational support is perceived to be discretionary moderates the relationship between evaluations of support and outcomes.

In support of the basic predictions of the social exchange perspective, evaluations of the social exchange relationship between the individual and the organization and its representatives have been shown to be related to a variety of outcomes relevant to employees and organizations, such as in-role performance, extra-role behavior, job satisfaction, and organizational commitment (Rhoades \& Eisenberger, 2002). The social exchange analysis also has clear implications for withdrawal from the job.

To the extent that individuals are satisfied with the "give and take" in the relationship, they will be motivated to continue the relationship, and the organization may expect individuals' active involvement in the job. However, when individuals are not satisfied with the relationship (i.e., because the benefits received from the other party in the relationship are perceived as too low in comparison to one's own input in the relationship), they may withdraw from the relationship (Thibaut \& Kelley, 1959), either by leaving the relationship entirely (i.e., turnover) or by other withdrawal behaviors, such as absenteeism, lateness, and non-work activities on the job (e.g., private e-mails, social talk). Evidence for these processes is found in research on perceived organizational support, perceived supervisor support, and psychological contracts (Eisenberger et al., 1986; Griffeth et al., 2000; Guzzo, Noonan, \& Elron, 1994; Robinson \& Rousseau, 1994; Wayne, Shore, \& Liden, 1997).

\section{Social Identity and Organizational Behavior}

Whereas reciprocity between the individual and another party lies at the core of the social exchange perspective, self-definition lies at the heart of the 
social identity perspective. Core to the social identity perspective on employee-organization relationships is the notion that group memberships are self-definitional to a greater or lesser degree (Ashforth \& Mael, 1989; Hogg \& Terry, 2000). Individuals may conceive of the self in terms of "we" rather than "I," including the group in their sense of self (i.e., collective self; Brewer \& Gardner, 1996; Turner, Hogg, Oakes, Reicher, \& Wetherell, 1987). The extent to which individuals define the self in terms of membership in the organization is reflected in the concept of organizational identification, the perceived oneness between self and organization (Ashforth \& Mael, 1989). The more people identify with a group or organization, the more the group's or organization's interests are incorporated in the self-concept, and the more likely the individual is to act with the organization's best interest in mind (Ashforth \& Mael, 1989; Dutton, Dukerich, \& Harquail, 1994; van Knippenberg \& Ellemers, 2003).

In support of the basic prediction that identification engenders a motivation to further the collective's interest, identification has been shown to be related to such behaviors as contributions to a public good (De Cremer \& Van Vugt, 1999), support for the organization (Mael \& Ashforth, 1992), in-role performance (James \& Greenberg, 1989; van Knippenberg, 2000), and extra-role behavior (Christ et al., 2003; Riketta \& van Dick, 2005; for overviews, see Haslam, 2001; Haslam, van Knippenberg, Platow, \& Ellemers, 2003; Hogg \& Terry, 2001). This is not to say, however, that identification always leads to positive outcomes. Turner, Pratkanis, and Samuels (2003), for instance, suggested that organizational identification may frustrate necessary organizational change if it leads organizational members to resist changes to a valued identity (cf. Rousseau, 1998; van Knippenberg, van Knippenberg, Monden, \& de Lima, 2002). Thus, the conclusion should be that identification motivates actions that are perceived to be in the collective's interest, even when in reality they may not be (van Knippenberg, 2000).

Like the social exchange perspective, the social identity perspective has clear implications for job withdrawal. Organizational identification may be expected to be related negatively to withdrawal from the job for at least two reasons. First, the more an individual identifies with the organization, the more the individual's self-concept is tied to the organization. Accordingly, withdrawal from the organization, especially permanent withdrawal (i.e., turnover), would affect the self-concept. People desire internal consistency and continuity over time in their self-concept. They are motivated to behave in ways that are consistent with their sense of self (e.g., pursue goals that are consistent with their values and the way they see themselves), and may resist changes to valued aspects of the self (Festinger, 1957; Rousseau, 1998; Sheldon \& Elliot, 1999; van Knippenberg et al., 2002). Therefore, withdrawal 
from the job is an action that is less likely to be taken the more people's sense of self is tied to the organization.

Second, we can assume that withdrawal from the job typically would be perceived as going against the organization's interest, and organizational identification motivates individuals to pursue that very interest. For that reason, too, the social identity perspective suggests a negative relationship between organizational identification and withdrawal from the job. In support of this proposition, research has shown that organizational identification is negatively related to turnover intention (Abrams, Ando, \& Hinkle, 1998; van Knippenberg \& van Schie, 2000), turnover (Mael \& Ashforth, 1995), and absenteeism (van Dick \& Wagner, 2002). ${ }^{2}$

\section{The Present Study}

Both the social exchange perspective and the social identity perspective make clear predictions about withdrawal intention and behavior, but propose different processes to underlie these outcomes. The social exchange perspective identifies dissatisfaction with the exchange relationship as a cause of withdrawal from the job, and felt obligation toward the exchange partner as motivation for active involvement in the organization and a reason to refrain from withdrawal. The social identity perspective, in contrast, identifies incorporation of the collective interest into the self-concept and a desire for self-consistency/continuity as causes of active involvement in the organization and, thus, as reasons not to withdraw from the job. These perspectives need not be in contradiction, and an obvious question to raise is how these processes relate to each other in determining organizational behavior.

A first observation in this respect is that, to a substantial extent, social exchange processes and social identity processes have different antecedents. Thus, in principle, they may operate relatively independently from one another. Positive evaluations of social exchange relationships - such as those reflected in evaluations of organizational support (Eisenberger et al., 1986), supervisor support (Kottke \& Shafranski, 1988), and psychological contracts (Robinson \& Rousseau, 1994) - derive from the perception that benefits received from the other party are high and commensurate with one's own

${ }^{2}$ It is possible that high identification, under certain circumstances, may be conducive to withdrawal. For instance, research on mergers and acquisitions has suggested that high identifiers may respond more negatively to a merger than low identifiers when the merger is perceived as a significant change in the organization's identity (van Knippenberg et al., 2002; van Leeuwen, van Knippenberg, \& Ellemers, 2003). However, it should be noted that, to our knowledge, no published study has documented a positive relationship between identification and job withdrawal (cf. Riketta, 2005). 
input in the relationship. Perceived fairness and organizational rewards and benefits, for instance, have been associated with positive evaluations of the exchange relationship (Rhoades \& Eisenberger, 2002; Tavares \& Caetano, 2003).

Organizational identification, in contrast, is rooted in context-dependent perceptions of similarity between self and organization (Ashforth \& Mael, 1989; Haslam, 2001). Because through identification the organization's image reflects on the self (Turner et al., 1987), organizational identification is strengthened by factors that render the organization attractive, such as its status or prestige (Mael \& Ashforth, 1992) and its distinctiveness (Dutton et al., 1994). It is conceivable that social exchange processes contribute to the attractiveness of the organization (e.g., being supportive of employees may contribute to an organization's attractiveness), but clearly they are not the only factor that renders an organization attractive. Moreover, in contrast to identification processes, social exchange processes do not rely on perceived similarity between self and organization.

Yet, this does not preclude the possibility that social exchange processes and social identity processes interact in affecting organizational behavior. Indeed, both social exchange processes and social identity processes in and of themselves may be enough to prevent withdrawal from the job, and to motivate individuals to be actively involved in the organization. In this sense, high identification as well as positive evaluations of the social exchange relationship may impose a psychological threshold to withdraw from the job, buffering the effects of factors that might motivate withdrawal, including low identification or low evaluations of the quality of social exchange.

High-quality social exchange (i.e., high support) may instill a sense of obligation that renders withdrawal less likely, even when identification is low, because the norm of reciprocity will motivate active involvement in the organization (cf. Eisenberger et al., 2001). Conversely, when high identification leads individuals to take the organization's interest to heart and links a sense of self-consistency to active involvement in the organization, withdrawal is less likely, even when the exchange relationship is perceived to be of low quality, because withdrawal would go against high identifiers' motivation to further the organization's interest and negatively impact their sense of self-consistency. Moreover, social exchange processes imply a relationship in which the individual and the organization are separate entities psychologically (Levinson, 1965; Rousseau \& Parks, 1993), and identification implies that the individual and the organization are one (i.e., in the sense that the organization is included in the individual's self-conception; Ashforth \& Mael, 1989; Turner et al., 1987). Accordingly, higher identification will lead individuals to evaluate their relationship with the organization less in terms of the quality of exchange because such evaluations are contingent on a psycho- 
logical linkage in which the organization is perceived as a separate entity (cf. Tyler \& Blader, 2000). Accordingly, we predict that evaluations of the quality of the exchange relationship and organizational identification interact in predicting job withdrawal, such that the relationship between evaluations of the exchange relationship and withdrawal is weaker the more strongly an individual identifies with the organization.

We test this hypothesis in two samples focusing on evaluations of the support received as an indicator of the quality of the exchange relationship (Rhoades \& Eisenberger, 2002). Both samples allowed us to test the interaction of organizational identification and support in predicting withdrawal from the job. However, they differ somewhat in the specific operationalizations of evaluations of support and job withdrawal. Study 1 focuses on evaluations of supervisor support and turnover intention. Study 2 focuses on evaluations of organizational support and absenteeism. To the extent that both samples yield the same pattern of results, these differences in operationalizations may bolster confidence in our findings and testify to their generalizability.

\section{Study 1}

Study 1 is a cross-sectional survey of bank accountants (i.e., private-sector employees) and focuses on the interaction of organizational identification and support from one's supervisor as a representative of the organization in prediction of turnover intention as an important aspect of withdrawal. Our hypothesis is that both evaluations of supervisor support and organizational identification are negatively related to turnover intention, but that evaluations of supervisor support are less related to turnover intention the more individuals identify with the organization.

\section{Method}

\section{Participants}

Supervisor support, organizational identification, and turnover intention were assessed in a questionnaire survey of 358 bank accountants (184 female, 168 male, 6 did not indicate gender) stemming from a large regional bank in Germany. Age was grouped as follows: younger than 25 years, $14 \%$; $25-34$ years, 29\%; 35-44 years, 29\%; $45-54$ years, $23 \%$; and older than 54 years, $4 \%$. Finally, $84 \%$ of the participants had been employed by the current company for more than 5 years. Response rate was $68 \%$. 


\section{Measures}

Evaluation of supervisor support was assessed with three items based on Hackman and Oldham (1980; cf. Kottke \& Shafranski, 1988). A sample item is "I'm satisfied with the amount of support I receive from my supervisor." Organizational identification was obtained with five items that have been previously shown to be a reliable measure (Van Dick, Wagner, Stellmacher, \& Christ, 2004). A sample item is "Being a member of my organization is a reflection of who I am." Finally, turnover intention was measured with two items inspired by Hackman and Oldham ("I frequently think of quitting" and "I often think of quitting this job").

All items were in German, and responses were assessed on a 6-point Likert scale ranging from 1 (strongly disagree) to 6 (strongly agree). Higher scores on the composite measures indicate more positive evaluations of supervisor support, higher organizational identification, and higher turnover intention, respectively.

\section{Results}

Descriptive statistics are presented in Table 1. Scale reliabilities were good for all scales. We conducted hierarchical regression analyses to test our hypothesis. In Step 1, we entered supervisor support and organizational identification; and in Step 2, we entered the interactions between supervisor support and organizational identification. Following Aiken and West (1991), we standardized the predictor variables before computing the interaction terms and entered the standardized scores. The results are presented in Table 2.

As expected, both supervisor support and identification were related negatively to turnover intention. Of most importance to the present discussion, the interaction of supervisor support and organizational identification

Table 1

Means and Intercorrelations for Variables: Study 1

\begin{tabular}{lccccr}
\hline Variable & $M$ & $S D$ & 1 & 2 & 3 \\
\hline 1. Supervisor support & 3.83 & 1.30 & .81 & & \\
2. Organizational identification & 4.60 & 0.96 & $.36^{* * *}$ & .86 & \\
3. Turnover intention & 2.10 & 1.39 & $-.45^{* * *}$ & $-.42^{* * *}$ & .89
\end{tabular}

Note. Coefficients alphas are displayed on the diagonal. $N=339$ (listwise). $* * * p<.001$. 
Table 2

Results of Hierarchical Regression Analysis: Study 1

\begin{tabular}{lcccc}
\hline & \multicolumn{4}{c}{ Turnover intention } \\
\cline { 2 - 5 } Variable & $b$ & $S E b$ & $\beta$ & $\Delta R^{2}$ \\
\hline Step 1 & & & & \\
$\quad$ Supervisor support (SS) & -0.49 & 0.07 & $-0.35^{* * *}$ & .13 \\
$\quad$ Organizational identification (OI) & -0.41 & 0.07 & $-0.29^{* * *}$ & .09 \\
Step 2 & & & & \\
$\quad$ SS $\times$ OI & 0.17 & 0.06 & $0.13^{* *}$ & .02 \\
\hline
\end{tabular}

Note. $N=339$ (listwise).

$* * p<.01 . * * * p<.001$.

was significant. Following Aiken and West (1991), we tested the simple slopes for respondents with higher identification (i.e., $1 S D$ above the mean) and respondents with lower identification (i.e., $1 S D$ below the mean) to determine the nature of the Supervisor Support $\times$ Organizational Identification interaction. In line with our hypothesis, supervisor support was strongly and negatively related to turnover intention for respondents with lower identification $(b=-.64, \beta=-.45, p<.001)$, while the relationship between supervisor support and turnover intention was weaker for highly identified employees $(b=-.31, \beta=-.22, p<.01$; see Figure 1$)$.

\section{Study 2}

Study 2 also provides information about the relationship between identification, support, and withdrawal and thus allows us to replicate the findings from the first sample. Because Study 2 also deviates from Study 1 in several respects, it also allows us to extend the findings from the first sample. First, it assesses evaluations of organizational support, rather than supervisor support. Second, it focuses on (self-reported) absenteeism as an indicator of withdrawal from the job, rather than turnover intention. ${ }^{3}$ Third, it concerns employees from the public sector (schoolteachers), rather than private-sector employees. Our hypothesis is that evaluations of organizational support and identification are negatively related to absenteeism, but that the relationship

${ }^{3} \mathrm{We}$ did not include a measure of turnover intention because, for schoolteachers in Germany, turnover is hardly an option and is extremely rare (van Dick \& Wagner, 2002). 


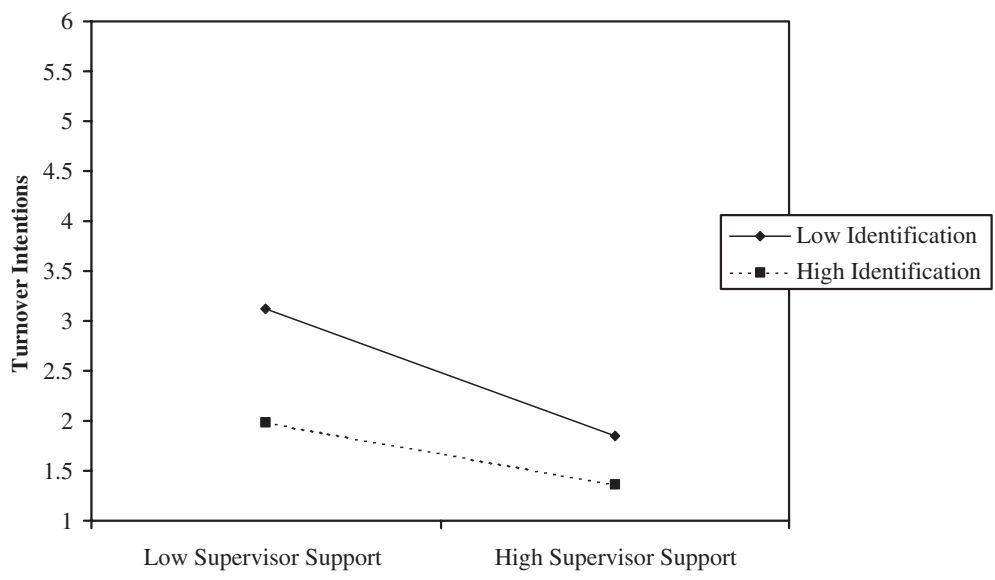

Figure 1. Turnover intention as a function of supervisor support and organizational identification: Study 1.

between perceived support and absenteeism is weaker as identification becomes stronger.

\section{Method}

\section{Participants}

Data regarding perceptions of organizational support, organizational identification, and absenteeism were assessed in a questionnaire survey of German schoolteachers as part of a larger project on schoolteachers' work life. The original sample consisted of 515 teachers. For reasons of economy, however, teachers were provided different versions of the questionnaire containing different subsets of concepts. The present analyses are based on the subsample in which organizational support and identification were assessed. We received 175 usable questionnaires (102 female and 73 male respondents), which contained all of the concepts that are relevant here. The overall response rate was $63 \%$. Respondents' mean age was 46.29 years $(S D=8.40)$, and their mean tenure was 18.84 years $(S D=10.08)$.

\section{Measures}

Perceptions of organizational support were assessed using a 12-item scale following Eisenberger et al. (1986). We formulated the items in a school- 
specific way, using "school administration" instead of "organization," for instance. Items included "School administration takes teachers' personal needs into account when making decisions" and "School administration recognizes and appreciates teachers' performance." Organizational identification was assessed with an instrument equivalent to what was used in Study 1 , but it was adapted to the school context (e.g., "Being a member of my school is an important reflection of who I am").

All items were in German, and responses were assessed on a 6-point scale ranging from 1 (strongly disagree) to 6 (strongly agree). Higher scores on the composite measures indicate higher organizational support and higher organizational identification, respectively. A single item requested respondents to indicate days of absenteeism from the job in the past 6 months. ${ }^{4}$

\section{Results}

Descriptive statistics are presented in Table 3. Scale reliabilities were sufficient for organizational support and organizational identification. As in Study 1, we conducted hierarchical regression analyses to test our hypotheses. In Step 1, we entered organizational support and organizational identification; and in Step 2, we entered the interactions between organizational support and organizational identification. We standardized the predictor variables before computing the interaction terms and entered the standardized scores. The results are presented in Table 4.

Table 3

Means and Intercorrelations for Variables: Study 2

\begin{tabular}{lccccr}
\hline Variable & $M$ & $S D$ & 1 & 2 & 3 \\
\hline 1. Perceived organizational support & 2.72 & 0.70 & .72 & & \\
2. Organizational identification & 4.33 & 1.11 & $.28^{* * *}$ & .80 & \\
3. Absenteeism & 3.71 & 8.86 & $-.30^{* * *}$ & $-.15^{*}$ & - \\
\hline
\end{tabular}

Note. Coefficients alphas are displayed on the diagonal. $N=167$ (listwise). $* p<.05 .{ }^{*} * * p<.001$.

\footnotetext{
${ }^{4}$ We acknowledge the added value of compiling different measures of absenteeism (e.g., summary scores, frequency of absences, frequency of periods of different duration; Schmidt \& Daume, 1996). Because of administrative limitations, it was not possible in the present context to obtain objective data or to measure different aspects of absenteeism with subjective methods.
} 
Table 4

Results of Hierarchical Regression Analysis: Study 2

\begin{tabular}{lcccc}
\hline & \multicolumn{4}{c}{ Absenteeism } \\
\cline { 2 - 5 } Variable & $b$ & $S E b$ & $\beta$ & $\Delta R^{2}$ \\
\hline Step 1 & & & & \\
$\quad$ Organizational support (OS) & -2.45 & 0.69 & $-0.28^{* * *}$ & .07 \\
$\quad$ Organizational identification (OI) & -0.65 & 0.68 & -0.07 & .01 \\
$\quad$ Step 2 & & & & \\
$\quad$ OS $\times$ OI & 1.30 & 0.57 & $0.17^{*}$ & .03 \\
\hline
\end{tabular}

Note. $N=167$ (listwise).

$* p<.05 . * * * p<.001$.

The interaction of organizational support and organizational identification was significant. We tested the simple slopes for respondents with higher identification (i.e., $1 S D$ above the mean) and respondents with lower identification (i.e., $1 S D$ below the mean) to determine the nature of the Organizational Support $\times$ Organizational Identification interaction. In line with our hypothesis, organizational support was negatively related to absenteeism for respondents with lower identification $(b=-3.73, \beta=-.42, p<.001)$, while the relationship between perceived organizational support and absenteeism was nonsignificant for highly identified employees $(b=-1.13, \beta=-.13, p>.21$; see Figure 2).

\section{General Discussion}

Integrating insights from social exchange and social identity perspectives on job withdrawal, we argued that both the felt obligation to reciprocate induced by organizational support and the motivation to further the organization's interest and to maintain self-consistency engendered by organizational identification would introduce a psychological threshold against withdrawal from the job. Moreover, we argued that evaluations of the organization's role in a social exchange relationship would become less of a concern to individuals the less the individual and the organization are separate psychological entities (i.e., with higher identification). Based on this reasoning, we predicted that evaluations of support and identification would interact in predicting job withdrawal. 


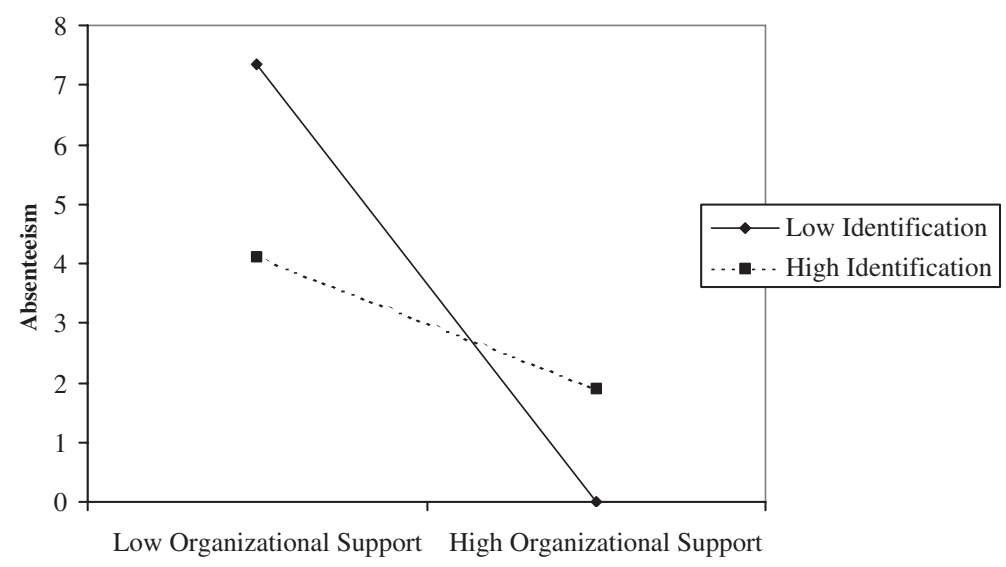

Figure 2. Absenteeism as a function of organizational support and organizational identification: Study 2.

The findings from two different samples confirm this hypothesis. Support and identification were negatively related to withdrawal; and in both samples, identification buffered the impact of support on withdrawal. The fact that this interaction was replicated across samples bolsters confidence in our findings, especially because the samples differed in type of organization (i.e., private sector vs. public sector), source of support (the organization vs. the supervisor as a representative of the organization), and specific indicator of withdrawal studied (turnover intention vs. absenteeism).

The present study seems to be a promising first step in integrating insights from social exchange and social identity perspectives on the psychological relationship between the individual and the organization. From that perspective, it would be valuable to extend the current analysis to other indicators of the quality of social exchange between individual and organization. The specific prediction that support and identification interact in predicting job withdrawal follows from the more general hypothesis that social exchange and social identity processes interact. Accordingly, support for our prediction obtained in the present study suggests, for instance, that organizational identification also may moderate the impact of evaluations of psychological contracts and psychological contract violations as indicators of the quality of the exchange relationship between the individual and the organization (Robinson \& Rousseau, 1994; Rousseau \& Parks, 1993). Testing this prediction in future research would seem to be a valuable further step in integrating social exchange and social identity perspectives on individual-organization relationships. 
In a similar vein, it would be valuable to extend the current analysis to other attitudes and behavior than withdrawal from the job. For instance, evaluations of the social exchange relationship and organizational identification both are associated with in-role and extra-role behavior (for an overview, see Rhoades \& Eisenberger, 2002; van Knippenberg, 2000). Therefore, an obvious question would be whether the interaction observed in the present study may also be observed for in-role and extra-role behavior. Exploring the combined effects of social exchange processes and social identity processes on these and other behaviors may advance our understanding of the factors governing these behaviors, and may lead to a more integrative understanding of the psychological relationship between the individual and the organization as a predictor of organizational behavior.

In line with our predictions, it seems that for high identifiers, psychological job withdrawal (either by intending to give up membership in the organization or by diminishing one's presence in the job context) is not a viable action to reciprocate a perceived lower quality of the exchange relationship. This raises the question of what is a viable response to low-quality exchange for high identifiers. Our analysis suggests that, at least to a certain extent, low-quality exchange is less of a concern only to high identifiers. Adopting Farrell's (1983; cf. Hirschman, 1970) terminology, loyalty (i.e., sticking with the organization without responding to a dissatisfying situation) rather than exit or neglect (i.e., withdrawal) may be the obvious course of action for high identifiers. To the extent that high identifiers are concerned with low-quality exchange, however, voice (i.e., attempts to change a dissatisfying situation) to try to actively change the situation without withdrawing from the job might be a more viable response for high identifiers. This is an interesting possibility that would be valuable to investigate in future research.

In Study 1, we focused on supervisors as representatives of the organization. Not all supervisors are seen as equally representative of the organization, however (Hogg \& van Knippenberg, 2003; van Knippenberg \& Hogg, 2003). An interesting question, therefore, is how differences in supervisors' representativeness of the organization affects the processes studied here. A first prediction might be that the less representative of the organization a supervisor is perceived to be, the less the psychological relationship between the individual and the organization will be affected by the exchange relationship with the supervisor (which is not to say that an individual may not seek to withdraw from a dissatisfying relationship with the supervisor).

On a different note, however, we should be careful not to conclude that supervisor behavior becomes less influential the more individuals identify with the organization. Rather, as Hogg and van Knippenberg (2003; van Knippenberg \& Hogg, 2003) argued, with higher identification, attention is likely to shift to different aspects of leader behavior. Hogg and van 
Knippenberg (2003) showed that as individuals identified more with the organization, leadership effectiveness was more contingent on the extent to which leaders were perceived to be representative (i.e., prototypical) of the collective and were seen to pursue the collective interest (also see van Knippenberg \& van Knippenberg, 2005). Clearly, then, even though evaluations of the social exchange relationship may become less influential as people identify more with organizations, leaders remain a powerful source of influence on organizational behavior, especially when they are seen to represent the collective.

A potential drawback of the present study is that both samples relied on mono-source data derived from a single questionnaire. Therefore, common method variance may enhance estimates of main effects. Importantly, however, common method variance cannot account for interactions in regression; indeed, it leads to an underestimation of statistical interactions (Evans, 1985; McClelland \& Judd, 1993). Despite the mono-source/ mono-method design, we may have some confidence in the interactions obtained.

This is not to say that the study is without limitations. A first thing to note is that the samples did not contain real behavioral measures. Study 1 focused on behavioral intention; while Study 2, although it focused on actual behavior, relied on self-reported behavior, rather than on a more objective measure of absenteeism. Moreover, this was only a single-item measure. Single-item measures are not necessarily problematic when they concern clear-cut, factual information, but there would have been added value in a multifaceted measure of absenteeism (cf. Footnote 4). An obvious direction for future research, therefore, would be to focus on more objective, fine-grained behavioral measures of withdrawal from the job (e.g., actual turnover, company records of absenteeism, and lateness).

A second limitation is that the cross-sectional design of the study renders it mute in matters of causality. Complementing the present study with (field) experimental data, therefore, would be valuable. A third limitation is that the study relied on measures of support that were rather specific to these samples, instead of applying more widely used measures, such as those developed by Eisenberger et al. (1986) and Kottke and Shafranski (1988). While the specific operationalizations may be valid in the context in which they were used, this lowers comparability with other studies in the field. Thus, follow-up research using different measures would be worthwhile.

From the point of view of organizational practice, the present findings imply that attempts to combat withdrawal from the job through investment in the exchange relationship (cf. Rhoades \& Eisenberger, 2002) are especially important when levels of organizational identification are low or decreasing. Put differently, the present findings may be taken to imply that either invest- 
ing in building a high-quality social exchange relationship or in building employee identification, contingent on what seems to be the more viable option in a given organizational context, may be an effective way to reduce or prevent withdrawal from the job.

\section{References}

Abrams, D., Ando, K., \& Hinkle, S. (1998). Psychological attachment to the group: Cross-cultural differences in organizational identification and subjective norms as predictors of workers' turnover intentions. Personality and Social Psychology Bulletin, 24, 1027-1039.

Aiken, L. S., \& West, S. G. (1991). Multiple regression: Testing and interpreting interactions. New York: Sage.

Armeli, S., Eisenberger, R., Fasolo, P., \& Lynch, P. (1998). Perceived organizational support and police performance: The moderating influence of socioemotional needs. Journal of Applied Psychology, 83, 288-297.

Ashforth, B. E., \& Mael, F. (1989). Social identity theory and the organization. Academy of Management Review, 14, 20-39.

Blau, P. M. (1964). Exchange and power in social life. New York: Wiley.

Brewer, M. B., \& Gardner, W. (1996). Who is this "we"? Levels of collective identity and self representations. Journal of Personality and Social Psychology, 71, 83-93.

Cascio, W. F. (1982). Costing human resources: The financial aspect of human behavior in organizations. Boston: Kent.

Christ, O., Van Dick, R., Wagner, U., \& Stellmacher, J. (2003). When teachers go the extra mile: Foci of organizational identification as determinants of different forms of organizational citizenship behavior among schoolteachers. British Journal of Educational Psychology, 73, 329-341.

De Cremer, D., \& Van Vugt, M. (1999). Social identification effects in social dilemmas: A transformation of motives. European Journal of Social Psychology, 29, 871-893.

Dutton, J. E., Dukerich, J. M., \& Harquail, C. V. (1994). Organizational images and member identification. Administrative Science Quarterly, 39, 239-263.

Eisenberger, R., Armeli, S., Rexwinkel, B., Lynch, P. D., \& Rhoades, L. (2001). Reciprocation of perceived organizational support. Journal of Applied Psychology, 86, 42-51.

Eisenberger, R., Cummings, J., Armeli, S., \& Lynch, P. (1997). Perceived organizational support, discretionary treatment, and job satisfaction. Journal of Applied Psychology, 82, 812-820. 
Eisenberger, R., Huntington, R., Hutchison, S., \& Sowa, D. (1986). Perceived organizational support. Journal of Applied Psychology, 71, 500-507.

Eisenberger, R., Stinglhamber, F., Vandenberghe, C., Sucharski, I., \& Rhoades, L. (2002). Perceived supervisor support: Contributions to perceived organizational support and employee retention. Journal of Applied Psychology, 87, 565-573.

Evans, M. G. (1985). A Monte Carlo study of the effects of correlated method variance in moderated multiple regression analysis. Organizational Behavior and Human Decision Processes, 36, 305-323.

Farrell, D. (1983). Exit, voice, loyalty, and neglect as responses to job dissatisfaction: A multidimensional scaling study. Academy of Management Journal, 26, 596-607.

Festinger, L. (1957). A theory of cognitive dissonance. Stanford, CA: Stanford University Press.

Gouldner, A. W. (1960). The norm of reciprocity: A preliminary statement. American Sociological Review, 25, 161-178.

Griffeth, R. W., Hom, P. W., \& Gaertner, S. (2000). A meta-analysis of antecedents and correlates of employee turnover: Update, moderator tests, and research implications for the next millennium. Journal of Management, 26, 463-488.

Guzzo, R. A., Noonan, K. A., \& Elron, E. (1994). Expatriate managers and the psychological contract. Journal of Applied Psychology, 79, 617-626.

Hackman, J. R., \& Oldham, G. R. (1980). Work redesign. Reading, MA: Addison-Wesley.

Haslam, S. A. (2001). Psychology in organizations: The social identity approach. Newbury Park, CA: Sage.

Haslam, S. A., van Knippenberg, D., Platow, M., \& Ellemers, N. (2003). Social identity at work: Developing theory for organizational practice. New York: Psychology Press.

Hirschman, A. O. (1970). Exit, voice, and loyalty: Responses to decline in firms, organizations, and states. Cambridge, MA: Harvard University Press.

Hogg, M. A., \& Terry, D. J. (2000). Social identity and self-categorization processes in organizational contexts. Academy of Management Review, $25,121-140$.

Hogg, M. A., \& Terry, D. J. (2001). Social identity processes in organizational contexts. Philadelphia: Psychology Press.

Hogg, M. A., \& van Knippenberg, D. (2003). Social identity and leadership processes in groups. Advances in Experimental Social Psychology, 35, $1-52$.

James, K., \& Greenberg, J. (1989). In-group salience, intergroup comparison, and individual performance and self-esteem. Personality and Social Psychology Bulletin, 15, 604-616. 
Johns, G. (2001). The psychology of lateness, absenteeism, and turnover. In N. Anderson, D. S. Ones, H. K. Sinangil, \& C. Viswesvaran (Eds.), Handbook of industrial and organizational psychology (Vol. 2, pp. 232252). London: Sage.

Kottke, J. L., \& Shafranski, C. E. (1988). Measuring perceived supervisory and organizational support. Educational and Psychological Measurement, $48,1075-1079$.

Levinson, H. (1965). Reciprocation: The relationship between man and organization. Administrative Science Quarterly, 9, 370-390.

Lynch, P. D., Eisenberger, R., \& Armeli, S. (1999). Perceived organizational support: Inferior versus superior performance by wary employees. Journal of Applied Psychology, 84, 467-483.

Mael, F., \& Ashforth, B. E. (1992). Alumni and their alma mater: A partial test of the reformulated model of organizational identification. Journal of Organizational Behavior, 13, 103-123.

Mael, F., \& Ashforth, B. E. (1995). Loyal from Day 1: Biodata, organizational identification, and turnover among newcomers. Personnel Psychology, 48, 309-333.

McClelland, G. H., \& Judd, C. M. (1993). Statistical difficulties of detecting interactions and moderator effects. Psychological Bulletin, 114, 376390.

Meyer, J. P., \& Allen, N. J. (1997). Commitment in the workplace. Thousand Oaks, CA: Sage.

Podsakoff, P. M., MacKenzie, S. B., Paine, J. B., \& Bachrach, D. G. (2000). Organizational citizenship behaviors: A critical review of the theoretical and empirical literature and suggestions for future research. Journal of Management, 26, 513-563.

Rhoades, L., \& Eisenberger, R. (2002). Perceived organizational support: A review of the literature. Journal of Applied Psychology, 87, 698-714.

Riketta, M. (2005). Organizational identification: A meta-analysis. Journal of Vocational Behavior, 66, 358-384.

Riketta, M., \& Van Dick, R. (2005). Foci of attachment in organizations: A meta-analytic comparison of the strength and correlates of workgroup versus organizational identification and commitment. Journal of Vocational Behavior, 67, 490-510.

Robinson, S. L., \& Rousseau, D. M. (1994). Violating the psychological contract: Not the exception, but the norm. Journal of Organizational Behavior, 15, 245-259.

Rousseau, D. M. (1998). Why workers still identify with organizations. Journal of Organizational Behavior, 19, 217-233.

Rousseau, D. M., \& Parks, J. M. (1993). The contracts of individuals and organizations. Research in Organizational Behavior, 15, 1-43. 
Schmidt, K. H., \& Daume, B. (1996). Beziehungen zwischen Aufgabenmerkmalen, Fehlzeiten, und Fluktuation [Relations between job characteristics, absenteeism, and turnover]. Zeitschrift für Arbeits und Organisationspsychologie, 40, 181-189.

Sheldon, K. M., \& Elliot, A. J. (1999). Goal striving, need satisfaction, and longitudinal well-being: The self-concordance model. Journal of Personality and Social Psychology, 76, 482-497.

Shore, L. M., \& Tetrick, L. E. (1991). A construct validity study of the Survey of Perceived Organizational Support. Journal of Applied Psychology, 76, 637-643.

Tavares, S., \& Caetano, A. (2003, May). Perceived HRM practices and organizational commitment: The mediating role of social exchange processes. Paper presented at the $\mathrm{XI}^{\text {th }}$ European Congress on Work and Organizational Psychology, Lisbon, Portugal.

Thibaut, J., \& Kelley, H. H. (1959). The social psychology of groups. New York: Wiley.

Turner, J. C., Hogg, M. A., Oakes, P. J., Reicher, S. D., \& Wetherell, M. S. (1987). Rediscovering the social group: A self-categorization theory. Oxford, UK: Blackwell.

Turner, M. E., Pratkanis, A. R., \& Samuels, T. (2003). Identity metamorphosis and groupthink prevention: Examining Intel's departure from the DRAM industry. In S. A. Haslam, D. van Knippenberg, M. J. Platow, \& N. Ellemers (Eds.), Social identity at work: Developing theory for organizational practice (pp. 117-136). New York: Psychology Press.

Tyler, T. R., \& Blader, S. L. (2000). Cooperation in groups: Procedural justice, social identity, and behavioral engagement. Philadelphia: Psychology Press.

Van Dick, R., \& Wagner, U. (2002). Social identification among school teachers: Dimensions, foci, and correlates. European Journal of Work and Organizational Psychology, 11, 129-149.

Van Dick, R., Wagner, U., Stellmacher, J., \& Christ, O. (2004). The utility of a broader conceptualization of organizational identification: Which aspects really matter? Journal of Occupational and Organizational Psychology, 77, 171-191.

van Knippenberg, B., \& Van Knippenberg, D. (2005). Leader self-sacrifice and leadership effectiveness: The moderating role of leader prototypicality. Journal of Applied Psychology, 90, 25-37.

van Knippenberg, D. (2000). Work motivation and performance: A social identity perspective. Applied Psychology: An International Review, 49, 357-371.

van Knippenberg, D., \& Ellemers, N. (2003). Social identity and group performance: Identification as the key to group-oriented efforts. In 
S. A. Haslam, D. van Knippenberg, M. J. Platow, \& N. Ellemers (Eds.), Social identity at work: Developing theory for organizational practice (pp. 29-42). New York: Psychology Press.

van Knippenberg, D., \& Hogg, M. A. (2003). A social identity model of leadership effectiveness in organizations. Research in Organizational Behavior, 25, 243-295.

van Knippenberg, D., Van Knippenberg, B., Monden, L., \& De Lima, F. (2002). Organizational identification after a merger: A social identity perspective. British Journal of Social Psychology, 41, 233-252.

van Leeuwen, E., Van Knippenberg, D., \& Ellemers, N. (2003). Continuing and changing group identities: The effects of merging on social identification and in-group bias. Personality and Social Psychology Bulletin, 29, 679-690.

van Knippenberg, D., \& Van Schie, E. C. M. (2000). Foci and correlates of organizational identification. Journal of Occupational and Organizational Psychology, 73, 137-147.

Wayne, S. J., Shore, L. M., \& Liden, R. C. (1997). Perceived organizational support and leader-member exchange: A social exchange perspective. Academy of Management Journal, 40, 82-111. 